\title{
Awareness, Attitudes and Behaviours of Medicine, Dentistry, Nursing and Midwifery Students on Eye Health: A Cross-sectional Study
}

\section{Tıp, Diş Hekimliği, Hemşirelik ve Ebelik Öğrencilerinin Göz Sağlığı Konusunda Farkındalık, Tutum ve Davranış/arı: Kesitsel Çalışma}

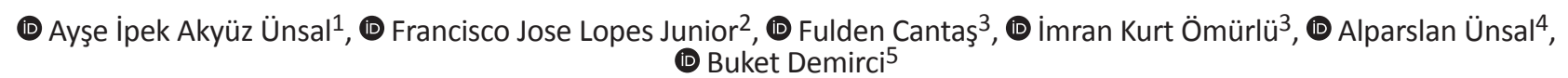

\author{
${ }^{1}$ Aydın Adnan Menderes University Faculty of Medicine, Department of Ophthalmology, Aydın, Turkey \\ ${ }^{2}$ Aydın Adnan Menderes University Faculty of Medicine, Aydın, Turkey \\ ${ }^{3}$ Aydın Adnan Menderes University Faculty of Medicine, Department of Biostatistics, Aydın, Turkey \\ ${ }^{4}$ Aydın Adnan Menderes University Faculty of Medicine, Department of Radiology, Aydın, Turkey \\ ${ }^{5}$ Aydın Adnan Menderes University Faculty of Medicine, Department of Medical Pharmacology, Aydın, Turkey
}

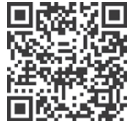

Keywords

Rational drug usage, knowledge, education, eye health, health, student

Anahtar Kelimeler

Akılcı ilaç kullanımı, bilgi, eğitim, göz sağlığı, sağlık, öğrenci

Received/Geliş Tarihi : 09.01.2021

Accepted/Kabul Tarihi : 05.02.2021

doi:10.4274/meandros.galenos.2021.85579

Address for Correspondence/Yazışma Adresi: Ayşe İpek Akyüz Ünsal MD,

Aydın Adnan Menderes University Faculty of Medicine, Department of Ophthalmology,

Aydın, Turkey

Phone : +90 5325201124

E-mail : ipekunsal@yahoo.com

ORCID ID: orcid.org/0000-0001-5260-674X

(C) Meandros Medical and Dental Journal, Published by Galenos Publishing House.

This is article distributed under the terms of the Creative Commons Attribution NonCommercial 4.0

International Licence (CC BY-NC 4.0).

\begin{abstract}
Objective: Increasing ones' knowledge level of eye health for preventive medicine and early treatment is essential. This study aimed to identify students who completed their second year of health education and students in their final month of education as regards their awareness, attitudes and behaviours about eye health, to determine their approach to medicine and to draw attention to the shortcomings of education.

Materials and Methods: A face-to-face questionnaire survey was performed to 337 second-year volunteers and to medicine, dentistry, nursery and midwife students in their final year of education. Data collected were evaluated by descriptive statistics and chi-square test.

Results: Students' response rate was very low (76.2\%-10.1\%), even if they voluntarily participated to the survey $(27.8 \%)$. They do not know about some of the basic knowledge such as uses of sunglasses, retinopathy of prematurity and coexistence of eye pathology in chronic diseases. They were not aware of the mandatory training on "rational drug treatment" in their curriculum. Although it is not legally possible, all students said they suggest accessibility of medications including antibiotics to people if they think they should use it.

Conclusion: Inadequate knowledge and misbeliefs on eye health among health care students were remarkable, which imply reconsideration of the educational curriculum. The suggestion rate of medications and beliefs on non-medical products were concerning. A general examination before graduation can help tackle this problem.
\end{abstract}

Öz

Amaç: Göz sağlığı konusunda bilgi düzeyinin artırılması hem koruyucu hekimlik, hem de erken dönemde tedaviye olanak vermesi yönünden oldukça önemlidir. Sağlık alanında eğitimlerinin ikinci yılını tamamlayan ve eğitimlerinin son ayına 
gelmiş öğrencilerin göz sağlığı konusundaki tutum ve davranışlarını belirlemeyi, ilaçlara yaklaşımlarını tespit etmeyi ve eğitimin eksik kalan yönlerine dikkat çekmeyi amaçladık.

Gereç ve Yöntemler: Tıp, diş hekimliği, hemşirelik ve ebelik fakülteleri 2. ve son sınıfta eğitimlerini tamamlamakta olan toplam 337 gönüllü öğrenciye yüz yüze görüşme metoduyla anket uygulandı. Sonuçlar tanımlayıcı istatistik ve ki-kare testi ile değerlendirildi. Bulgular: Gönüllü olarak ankete katılmayı kabul etseler bile $(\% 27,8)$, öğrencilerin sorulara cevap verme oranları oldukça düşüktü (\%76,2 ile \%10,1 aralığında). Güneş gözlüğünün kullanımı, prematüre retinopatisi, kronik hastalıklarda göz tutulumu gibi bazı temel bilgiler bilinmiyordu. Ders programlarında olan "akılcı ilaç kullanımı" zorunlu eğitiminin farkında değillerdi. Hukuksal olarak uygun olmasa da, tüm öğrenciler antibiyotikleri dahi çevrelerindeki kişilere kullanılmasını uygun gördüklerinde önerdiklerini bildirmişlerdir. Sonuç: Tüm öğrencilerin göz sağlığı konusunda yetersiz ve yanlış bilgileri dikkate değer olup, eğitim programları yeniden gözden geçirilmelidir. İlaçların önerilme oranı ve ilaç dışı ürünlere olan inanç endişe vericidir. Mezuniyetten hemen önce yapılacak genel bir sınav problemin çözümü için yardımcı olabilir.

\section{Introduction}

Education on preventive medicine is highly important in all fields of medicine as well as in ophthalmology (1). Thus, the prevalence of eye diseases like retinopathy of prematurity, cataracts can be reduced and possible complications like glaucoma, blindness can be prevented. With this we contribute to protect public health and reduce the budget allocated to treatment expenditures. Regardless of the socio-economic status of countries, cataracts, uncorrected refractive errors, glaucoma, age-related macular degeneration, and diabetic retinopathy are among the leading causes of blindness at the age of fifty and above (2). While cortical blindness, optic nerve abnormalities, retinopathy of prematurity, and cataracts are the leading causes of childhood blindness in developed countries; nutritional and infectious corneal opacities, cataracts, and premature retinopathy in developing and underdeveloped countries $(3,4)$. In a study in Turkey, the rate of blindness in childhood due to preventable and treatable diseases is as high as $69.9 \%(5)$.

Following the studies on "rational drug use" initiated by the World Health Organization (WHO) in 1994, T.C. The Ministry of Health, Turkey Pharmaceuticals and Medical Devices Agency of Turkey Pharmacovigilance Agency (TÜFAM) operating in the Directorate General after 2000 has given importance to rational drug use (6). The clinician has the responsibility to diagnose the disease, determine the treatment goals, choose a reliable and efficiently proven treatment, write prescriptions without mistakes, start the treatment by giving relevant instructions to the patients, follow the treatment and perform rational drug administration (6). The patient also has responsibilities of understanding the importance of his disease, applying his treatment correctly, using drugs correctly, and taking protective cautions. Any deficiency in one of these stages could deteriorate the effectiveness and safety of the treatment; medical errors can harm the patient and lead to the increase of expenditures in treatments (1).

Students who are studying in the fields of health such as medicine, dentistry, nursing, and midwifery can provide consultancy to patients in eye diseases as well as in all health problems, even before their graduation. When necessary, it is extremely important for the students to refer the patients to the clinician for early diagnosis. With their knowledge, beliefs, attitudes, and behaviors in terms of preventions of eye diseases, they can play an important role in preventive medicine for both their own eye health and people around them. On the other hand, awareness of the undergraduate of health sciences about conveying the necessary and information in a correct way about doctor's prescription, usage and side effects of the drugs, also not recommending any medication, prescription of drugs considering that this is out of their competence and that they have not yet had doctor-patient training could be a very important factor that will directly affect the success of treatment.

The aim of this study is to determine the roles of students in the rational use of drugs, level of knowledge, awareness, beliefs, attitudes, and behaviors in order to protect eye health as well as to draw attention to the missing points in medical education concerning eye health and the rational use of drugs.

\section{Materials and Methods}

The presented study is a cross-sectional survey study and the universe of the study were students of medicine, dentistry, nursing, and midwifery faculties 
who are completing the second year and final year of education at Aydın Adnan Menderes University. The questionnaire was applied to $2^{\text {nd }}$ year students considering that the first year is the starting of the university and that the uncertainty about profession decreases at the end of the second year, their awareness, attitudes, and behaviors start developing in their profession. Thus, better participation in the survey and they could be more careful in their answers. Since students voluntarily participated in the survey, no signed consent form was needed. In addition, with this application, we ensured that the students participating in the survey are above 18 years old. The survey was applied to the final year students because they have more knowledge, awareness, attitude, and behavior of their occupations. Since the aim of this survey is to evaluate the knowledge and awareness levels, attitudes, and behaviors of the students that will start working after graduation that will take place a month after the survey.

The study was conducted with volunteer students at the cafe, reading rooms of the faculties, and amphitheaters of the university between 6-18 May 2019 ( $n=337)$. The Non-Interventional Clinical Research Ethics Committee of Aydın Adnan Menderes University approved the survey (protocol no: 2019/74, date: 25.04 .2019) and the permissions were obtained from the Deans of the Medicine, Dentistry, Nursery, and Midwifery Faculties. The questions of the survey were compiled from the literature review.

The volunteers were evaluated in 3 parts. At first, the socio-demographic data like age, gender, education, and questioning frequent ocular problems like refraction error, dyschromatopsia, and existing ocular disease. The second part included the basic level of knowledge and data sources of students. In order to evaluate the aforementioned data, there are several questions like:

From which eye disease does sunglasses protect?

In which chronic diseases does ophthalmic involvement occur?

Write two of them, write down one of the eye diseases in premature newborns?

Write down a contagious eye disease?

Write one of a precaution that comes to mind to protect your eye health?

How often should a routine eye examination be performed?
Did you receive rational drug training?

Which institution do you report the adverse effect of the drugs?

Select the source of information you use to get information about eye health, In addition, in this section, students were asked to grade from 1 to 5 on their own knowledge about drugs (1: Very bad, 2: Bad, 3: Medium, 4: Good, 5: Very good). They were asked how they perceive themselves about the route of administration, pharmacological properties, indications, side effects, contraindications, interactions (drug/nutrient), bioequivalence of drugs, and drug use in pregnancy or childhood. In the third part, there were questions to determine the belief, attitudes, and behavioral characteristics of the students. The related questions were:

Do you use sunglasses?

Do you use protective glasses during risky conditions?

Do you believe that reading books is harmful to the eyes?

Do you think devices such as mobile phones and tablets cause eye disease?

What is your trust rank in healthcare professions?

What do you think about products licensed by the Ministry of Food, Agriculture, and Livestock of Turkey (TCGTHB legal abbriviation in Turkish)?

What are your thoughts on imported drugs?

Do you recommend drugs for eye diseases?

Which drugs do you use and recommend most?

Since the students did not answer every question given in the questionnaire, the answers were evaluated not according to the number of questionnaires distributed in the classroom, but giving a proportion of answers to every question itself.

\section{Statistical Analysis}

The data were analyzed with the SPSS (version 21) statistical package program. Descriptive statistics of quantitative variables are expressed as mean \pm standard deviation, and qualitative variables are expressed as frequency (percentage). Chi-square analysis was used for the independent analysis of qualitative variables. Values of $p<0.05$ were considered statistically significant.

\section{Results}

\section{Socio-demographic Findings}

All the data of the 337 participants were given in Table 1. 
Fifty-five (23\%) in a total of 240 students in the $2^{\text {nd }}$ year of Medicine (MED2); 39 (22.3\%) of 175 of $6^{\text {th }}$ year medical students (MED6) participated in the study. The number of dentistry $2^{\text {nd }}$ year (DEN2) was 38 (33\%) out of 115 students, while $5^{\text {th }}$-year dentistry (DEN5), only 6 of 18 accepted to participate in our survey. Of 288 nursing students of $2^{\text {nd }}$ (NUR2) and 202 students $4^{\text {th }}$ year (NUR4) $46(16 \%)$ and $71(35.1 \%)$, respectively, took part in our study. Sixty two students (66\%) out of 90 students in midwifery $2^{\text {nd }}$ year (MID2) and 20 (24.1\%) out of 83 students in the $4^{\text {th }}$ year of midwifery (MID4) participated in our study.

The distribution of the students were as follows; $94(27.9 \%)$ of the students in medicine, $44(13.1 \%)$ in dentistry, 117 (34.7\%) in nursing, and $82(24.3 \%)$ in midwifery faculty. Of all the participants, 217 (64.4\%) were female and 120 (35.6\%) were male and the average age was found to be $21.5 \pm 1.8$ years old. Three hundred and thirty-three students in total answered the question "Do you have any eye diseases?" 34 students (10.1\%) answered the question "yes"; some of them had keratoconus, cataract, and allergic eye diseases. The refraction error was frequent (51.6 $\%)$ among students and most of them were myopic (27.6\%). Refractive errors were corrected by using glasses 109 (71.7\%), 23 (15.1\%) lenses, and 18 (11.8\%) glasses \& lenses together. One of the students of MED6 had a laser operation for his myopia. None of the students had dyschromatopsia among the ones who had color vision examination (51.8\%).

Level of Knowledge on Eye Diseases and Sources of Information The Students Refer to

Participation in the questions of this section and evaluation results for each class are shown in Table 2. It was remarkable that the students did not fill the questions requiring further information.

\begin{tabular}{|c|c|c|c|c|c|c|c|c|}
\hline \multirow{2}{*}{ Socio-demographics } & \multicolumn{8}{|c|}{ Education } \\
\hline & MED2 & MED6 & DEN2 & DEN5 & NUR2 & NUR4 & MID2 & MID4 \\
\hline Age & $20.7 \pm 1.3$ & $24.5 \pm 1$ & $20.4 \pm 0.9$ & $23.2 \pm 0.4$ & $20.2 \pm 0.7$ & $22.6 \pm 1.2$ & $20.1 \pm 1$ & $22.2 \pm 0.7$ \\
\hline \multicolumn{9}{|l|}{ Sex } \\
\hline Female & 25 & 19 & 20 & 5 & 28 & 41 & 60 & 19 \\
\hline Male & 30 & 20 & 18 & 1 & 18 & 30 & 2 & 1 \\
\hline \multicolumn{9}{|l|}{ Eye disease } \\
\hline Yes & 6 & 13 & 7 & 0 & 1 & 6 & 1 & 0 \\
\hline No & 49 & 26 & 31 & 6 & 45 & 65 & 59 & 20 \\
\hline \multicolumn{9}{|l|}{ Refractive errors } \\
\hline No & 21 & 10 & 11 & 3 & 27 & 36 & 34 & 7 \\
\hline Myopic & 15 & 17 & 8 & 1 & 10 & 16 & 13 & 5 \\
\hline Hypermetropic & 0 & 2 & 0 & 0 & 0 & 1 & 1 & 0 \\
\hline Astigmatism & 0 & 1 & 4 & 0 & 1 & 2 & 0 & 0 \\
\hline Myopia-astigmatism & 14 & 7 & 11 & 1 & 7 & 10 & 5 & 7 \\
\hline \multicolumn{9}{|c|}{ How do you correct the refractive errors? } \\
\hline Glasses & 20 & 15 & 15 & 0 & 17 & 21 & 15 & 7 \\
\hline Lens & 8 & 4 & 2 & 1 & 1 & 4 & 1 & 2 \\
\hline Laser & 0 & 1 & 0 & 0 & 0 & 0 & 0 & 0 \\
\hline Glasses + lens & 1 & 5 & 4 & 1 & 0 & 3 & 4 & 0 \\
\hline \multicolumn{9}{|l|}{ Color vision test } \\
\hline Examined & 29 & 27 & 21 & 3 & 15 & 36 & 33 & 7 \\
\hline Not examined & 23 & 11 & 17 & 3 & 31 & 35 & 28 & 11 \\
\hline
\end{tabular}




\begin{tabular}{|c|c|c|c|c|c|c|c|c|}
\hline & \multicolumn{8}{|c|}{ Level of education } \\
\hline & MED2 & MED6 & DEN2 & DEN5 & NUR2 & NUR4 & MID2 & MID4 \\
\hline \multicolumn{9}{|c|}{ Write a disease that can be prevent with sunglasses } \\
\hline Right/wrong & $3 / 9$ & $8 / 11$ & $3 / 15$ & - & $6 / 16$ & $7 / 18$ & $1 / 23$ & $2 / 5$ \\
\hline \multicolumn{9}{|c|}{ During the course of which chronic diseases eye involvement occurs } \\
\hline 1 Right/2 right/wrong & $12 / 3 / 0$ & $14 / 22 / 0$ & $4 / 7 / 4$ & $2 / 3 / 0$ & $7 / 29 / 2$ & $24 / 28 / 3$ & $11 / 16 / 2$ & $4 / 4 / 2$ \\
\hline \multicolumn{9}{|c|}{ Write any eye disease seen in premature newborn } \\
\hline Right/wrong & $5 / 4$ & $19 / 10$ & $4 / 5$ & $0 / 1$ & $3 / 7$ & $8 / 17$ & $9 / 7$ & $9 / 2$ \\
\hline \multicolumn{9}{|l|}{ Write down any contagious eye disease } \\
\hline Right/wrong & $11 / 3$ & $25 / 5$ & $6 / 1$ & - & $8 / 6$ & $14 / 11$ & $11 / 7$ & $6 / 1$ \\
\hline \multicolumn{9}{|c|}{ Write down what you know about the prevention of eye diseases } \\
\hline Right/wrong & $37 / 1$ & $24 / 3$ & $26 / 7$ & $4 / 0$ & $30 / 8$ & $45 / 7$ & $40 / 7$ & $9 / 6$ \\
\hline \multicolumn{9}{|c|}{ How often should the routine eye examination be performed? } \\
\hline Every 6 months & 29 & 14 & 25 & 3 & 17 & 36 & 34 & 9 \\
\hline Every 12 months & 13 & 17 & 11 & 2 & 24 & 26 & 22 & 9 \\
\hline Every 2 years & 5 & 4 & 1 & 1 & 3 & 6 & 3 & 2 \\
\hline Every 3 year & 3 & 2 & 0 & 0 & 0 & 0 & 0 & 0 \\
\hline \multicolumn{9}{|c|}{ Have you received training on the rational use of drugs? } \\
\hline Yes/No & $14 / 39$ & $33 / 6$ & $5 / 32$ & $6 / 0$ & $11 / 34$ & $25 / 45$ & $47 / 15$ & $16 / 1$ \\
\hline \multicolumn{9}{|c|}{ To which institution do you report the adverse effect of the drugs? } \\
\hline Right/Wrong & $4 / 16$ & $24 / 11$ & $2 / 22$ & $0 / 5$ & $5 / 35$ & $15 / 44$ & $6 / 49$ & $1 / 14$ \\
\hline \multicolumn{9}{|c|}{ What are your sources of information for eye health and medications? } \\
\hline Computer software $\left(\mathrm{RxPharma}^{\circledR}\right)$ & 1 & 1 & 1 & 1 & 1 & 1 & 1 & 1 \\
\hline Friend & 5 & 7 & 6 & 2 & 4 & 4 & 3 & 1 \\
\hline Book & 7 & 17 & 2 & 1 & 9 & 20 & 4 & 1 \\
\hline Internet & 22 & 18 & 19 & 3 & 25 & 33 & 18 & 4 \\
\hline Lecture notes & 6 & 11 & 1 & 2 & 6 & 10 & 4 & 2 \\
\hline Optician & 14 & 3 & 9 & - & 8 & 8 & 7 & 4 \\
\hline Pharmacy & 10 & 1 & 6 & 2 & 6 & 9 & 11 & 8 \\
\hline I don't need & 2 & 4 & 1 & - & 1 & 1 & - & - \\
\hline Doctor & 40 & 22 & 25 & 5 & 33 & 56 & 58 & 18 \\
\hline $\begin{array}{l}\text { Level of knowledge of the drugs route of } \\
\text { administration }\end{array}$ & $3.2 \pm 1.1$ & $3.2 \pm 0.8$ & $3.5 \pm 1.3$ & $3.6 \pm 0.5$ & $3.9 \pm 0.8$ & $4.0 \pm 0.7$ & $3.6 \pm 0.8$ & $4.2 \pm 0.5$ \\
\hline $\begin{array}{l}\text { Level of knowledge of drugs } \\
\text { pharmacological properties }\end{array}$ & $2.7 \pm 1.1$ & $3.0 \pm 0.7$ & $2.9 \pm 1.2$ & $3.4 \pm 0.5$ & $3.4 \pm 1$ & $3.2 \pm 0.8$ & $3.1 \pm 0.7$ & $3.1 \pm 0.6$ \\
\hline Level of knowledge of drugs indications & $2.6 \pm 1.1$ & $3.4 \pm 0.7$ & $3.1 \pm 1.2$ & $4.0 \pm 0.7$ & $3.2 \pm 0.9$ & $3.3 \pm 0.7$ & $3.1 \pm 0.6$ & $3.3 \pm 0.7$ \\
\hline Level of knowledge of drugs side effects & $2.7 \pm 1.1$ & $3.1 \pm 0.6$ & $2.9 \pm 1.2$ & $3.6 \pm 0.5$ & $3.1 \pm 0.9$ & $3.1 \pm 0.7$ & $3.1 \pm 0.6$ & $3.4 \pm 0.6$ \\
\hline $\begin{array}{l}\text { Level of knowledge of contraindications of } \\
\text { drugs }\end{array}$ & $2.4 \pm 1.1$ & $3.0 \pm 0.7$ & $2.6 \pm 1.4$ & $3.6 \pm 0.5$ & $3.0 \pm 0.9$ & $3.2 \pm 0.7$ & $2.9 \pm 0.7$ & $3.5 \pm 0.6$ \\
\hline Level of knowledge of drug interactions & $2.5 \pm 1.1$ & $2.8 \pm 0.9$ & $2.8 \pm 1.2$ & $3.4 \pm 0.5$ & $3.1 \pm 0.9$ & $2.9 \pm 0.8$ & $3.0 \pm 0.7$ & $3.3 \pm 0.7$ \\
\hline $\begin{array}{l}\text { Level of knowledge of drugs administration } \\
\text { in special situations }\end{array}$ & $2.4 \pm 1.0$ & $2.7 \pm 0.8$ & $3.1 \pm 1.1$ & $3.6 \pm 0.5$ & $3.1 \pm 1.0$ & $3.1 \pm 0.9$ & $3.3 \pm 0.8$ & $3.6 \pm 0.7$ \\
\hline Level of knowledge of drug bioequivalence & $2.3 \pm 1.1$ & $2.6 \pm 0.8$ & $2.9 \pm 1.3$ & $3.0 \pm 0.0$ & $2.8 \pm 0.9$ & $3.0 \pm 0.8$ & $3.0 \pm 0.8$ & $3.1 \pm 0.7$ \\
\hline
\end{tabular}


Those who answered the question "Which disease do sunglasses protect?" Such as cataracts and cancer are correct, and those who say they do not protect are considered incorrect answers. $82.9 \%$ (76 people) of all $2^{\text {nd }}$-year students who participated in the survey gave the wrong answers to this question, MID2 group had the highest percentage of wrong answers; only 1 out of 24 students could answer correctly. It was surprising that most students about to start professional life did not answer, and $66.7 \%$ of the respondents gave wrong answers.

When we asked the students to give any two examples to the question of which chronic diseases have ocular involvement during their course (hypertension, diabetes, an endocrinological or rheumatological disease), the total number of students who answered the question was 203. NUR2, NUR4, MID2, and MID4 students wrote answers such as miosis, rash, dryness. Although there were no incorrect answers in the MED2 and MED6 groups, we found that the rates of double correct answers were low (20\% and $61.1 \%$, respectively).

We observed that a total of 110 students answered the question "What kind of eye disease develops in a premature newborn?". Considering that there are 337 students participating in the questionnaire, $2 / 3$ of the students could not answer this question. While we accepted answers such as blindness, strabismus, refractive error, and ophthalmopathy/retinopathy as correct, we considered responses such as color blindness, stye, and jaundice as wrong answers. Fiftyseven out of 110 gave correct answers (51.8\%).

One hundred fifteen students responded to "Write down a contagious eye disease" and 81 out of 115 gave correct answers (70.4\%) such as conjunctivitis. However, there were wrong responses like redness, glaucoma, and miosis.

Two hundred fifty four students responded to the question "Please write something that comes to your mind to protect your eye health"; 215 of these students (84.6\%) said "I pay attention to my nutrition, my sleep, I use glasses" and their answers were accepted as correct. Ambiguous answers such as "I go to the doctor, I take care of my eye"" were considered incorrect. The MID4 group, among which 15 people answered this question had $60 \%$, being the least correct answer rate.
Another question including eye health was "How often should a routine eye examination be done?" 167 (52.0\%) out of 321 marked "once in 6 months", and $124(38.6 \%)$ "once a year". Those who marked the option every 2 years or 3 years were in the minority.

All of the students ( $n=239$; MED6, DEN5, NUR2, NUR4, MID2, and MID4) except MED2 and DEN2 stated that they received courses, medical pharmacology, and treatment training during their education as a response to the "Have you received training on rational drug use?" question. Despite this, 44.6\% (111 people) declared that they did not receive rational medicine training. $47.7 \%$ of the 239 students stated that they received this training from the curriculum or at the congresses they attended.

Two hundred fifty three students responded to "Which institution do you report the adverse effect?", only 57 of them (22.5\%) were able to give the "TÜFAM" correct answer. Answers such as "to the WHO and the pharmaceutical company" were considered incorrect. Of the 35 MED6 students who answered this question, only 24 of them were able to give the "TÜFAM" correct answer.

When we asked the students about their sources of information, the response rate was high. All students who selected several options at the same time chose the options "I ask the doctor" with a maximum of 257 answers and "I check from the internet" with 143 answers. Seven students stated that they use a computer software program (RxMedia ${ }^{\circledR}$ ), 9 students stated that they do not need to ask and 32 students preferred to ask their friends.

We asked students to rate themselves between 1 (very poor) and 5 (very good) points for their level of knowledge about drugs. The MID4 and NUR4 groups gave $4.2 \pm 0.5$ and $4.0 \pm 0.7$ points to themselves regarding the route of administering the drugs, the MED2 and MED6 groups gave $3.2 \pm 1.1$ and $3.2 \pm 0.8$ points to themselves. The DEN5 $(3.4 \pm 0.5)$ and NUR2 $(3.4 \pm 1)$ groups found themselves in the best position regarding the pharmacological properties of the drugs. NUR4 (3.2 \pm 0.8$),$ MID2 $(3.1 \pm 0.7)$ and MID4 (3.1 \pm 0.6$)$ students rated themselves more knowledgeable than MED6 (3.0 \pm 0.7$)$. Six students in the DEN5 group $(4.0 \pm 0.7)$ and those in the MED6 $(3.4 \pm 0.7)$ group gave themselves high scores in terms of their knowledge on the indications of drugs followed by NUR4 $(3.3 \pm 0.7)$ and MID4 $(3.3 \pm 0.7)$ students. Evaluating themselves 
about the side effects of drugs, 6 students in the DEN5 group (3.6 \pm 0.5$)$ and those in the MID4 $(3.4 \pm 0.6)$ group gave high scores themselves. MED6, NUR2, NUR4, MID2 scores were similar to 3.1. Six students in the DEN5 group (3.6 \pm 0.5$)$ and those in the MID4 (3.5 \pm 0.6$)$ group gave themselves the highest score about the contraindications of the drugs. Among the students who scored their knowledge on drug interactions, 6 students from the DEN5 group (3.4 \pm 0.5$)$, the MID4 group $(3.3 \pm 0.7)$ gave higher points to themselves higher than the MED6 group (2.8 \pm 0.9$)$. When we evaluated the administration of drugs to patients with special conditions, 6 students in the DEN5 group (3.6 \pm 0.5$)$ and the MID4 (3.6 \pm 0.7$)$ group scored themselves high, leaving MED6 students $(2.7 \pm 0.8)$ behind. In terms of drug bioequivalence, MED2 (2.3 \pm 1.1$)$ and MED6 students $(2.6 \pm 0.8)$ got the lowest score, while all other groups gave themselves higher scores than MED students, regardless of differences in the year of study. In almost all evaluations, the scores from NUR2, NUR4, MID2, and MID4 students were above the average number (3), and in some questions, it was higher than MED6 students.

\section{Belief, Attitude, and Behavior Characteristics}

Answers to the questions of this section as well as results for each year and education background are shown in Table 3. Sixty-six (19.6\%) students answered yes, 176 students (52.2\%) answered sometimes and 95 students (28.2\%) answered no to the question "Do you use sunglasses?". The highest rate of sunglasses use was among the MED6 group with 13 (33.3\%). A total of 155 students (46.7\%) answered yes, while 177 (53.3\%) answered no to the question "Do you use protective glasses for risky jobs?". Five students in DEN5 (83.3\%) and 24 students in DEN2 (64.9\%) groups protect themselves in risky jobs most among other groups, while those who protect the least are the MID2 group (18 people, 29.5\%) and the MID4 group (7 people, 35\%). A total of 130 (39\%) participants said yes, while $203(61 \%)$ answered no to the question, "Is reading a book harmful for eyes?". Those who believed that reading books are harmful to the eyes were the NUR4 group with 33 (46.5\%) and MED6 with 18 (46.2\%). Those who believed that reading books do not disturb the eyes were 47 students in the MID2 group, saying no with $75.8 \%$.

Three hundred thirteen students (93.2\%) answered yes and 23 students (6.8\%) answered no to the question "Do you think using mobile phones and tablets causes eye disease?". The MED6 group has the highest rate with 6 students responding no to this question (15.4\%).

When we asked about their beliefs/trust in the professional groups in eye health and asking to rank out of 5 points, the most trusted group was ophthalmologists scoring between 4.7 and 5 . In the second-rank, unlike all other students, 3 points were given to nurses at NUR2 group students, family physicians (2.7 points) were less trusted than nurses (3 points) on eye health.

We asked the students about their beliefs about TCGTHB approved products and drugs from abroad. The opinion about whether the products approved by the TCGTHB are more effective than drugs was not statistically different between the study groups $(p=0.084)$. Two hundred forty two $(80.1 \%)$ out of 302 students who answered this question thought that the products approved by TCGTHB were not more effective. Students of MED6 group stated that they found these products less reliable than drugs, unlike other groups (MED2, NUR2, NUR4, and MID2), with a rate of $94.9 \%(p=0.003)$. Six students from the DEN5 group also found these products unreliable. $A$ hundred twenty three (40.6\%) of all students believed that these products had fewer side effects than drugs, MED6 group students did not agree with this point of view with a rate of $94.9 \%$ and made a difference compared to all other groups $(p=0.001)$. Ninety four students $(30.9 \%)$ shared the opinion that TCGTHB approved products are suitable for most patients, while according to 210 students $(69.1 \%)$ they would not be suitable $(p=0.004)$. MED6 group students agree with $94.9 \%$ of the opinion that these products are not suitable for most patients. All student groups (302 students) agreed with $70.5 \%$ that the products will reduce the cost of treatment due to fast and precise treatment $(p=0.248)$. The MED6 group students who found these products unreliable at a rate of $94.9 \%$, stated that the side effects were not less than the drug and that they would not be suitable for most patients agreed with the idea that they could reduce treatment costs by $58.3 \%$.

The students $(n=309)$ had different opinions according to their years of study on whether or not the drugs from abroad are more effective. In general, $49.8 \%$ overall agree that it is more effective. While 
MED2 said that it was $63 \%$ effective, MED6 agreed also at a rate of $40.5 \%$. They declared that they find these drugs effective at the following rates; DEN2 79.4\%, DEN5 60.0\%, NUR2 59.1\%, NUR4 35.8\%, MID2 $36.7 \%$ and MID4 50.0\%. In comparison between group results on the effectiveness of drugs from abroad;
MED2 is different from MED6, NUR4, and MID2; MED6 is different from DEN2; DEN2 found different from NUR4 and MID2 $(p<0.001)$. The rate of those who found the drugs from abroad more reliable was $34.6 \%$. There were statistically significant differences between groups and these are as follows; MED2 and

\begin{tabular}{|c|c|c|c|c|c|c|c|c|c|}
\hline Education & MED2 & MED6 & DEN2 & DEN5 & NUR2 & NUR4 & MID2 & MID4 & $p$ \\
\hline \multicolumn{9}{|l|}{ Do you use sunglasses? } & \\
\hline Yes & 13 & 13 & 8 & 2 & 8 & 13 & 8 & 1 & \\
\hline Sometimes & 25 & 19 & 19 & 3 & 21 & 45 & 32 & 12 & \\
\hline No & 17 & 7 & 11 & 1 & 17 & 13 & 22 & 7 & \\
\hline \multicolumn{9}{|c|}{ Do you use protective glasses for works with risks? } & \multirow{3}{*}{ - } \\
\hline Yes/no & $25 / 29$ & $20 / 17$ & $24 / 13$ & $5 / 1$ & $21 / 25$ & $35 / 36$ & $18 / 43$ & $7 / 13$ & \\
\hline$\%$ of yes & 46.3 & 54.1 & 64.9 & 83.3 & 45.7 & 49.3 & 29.5 & 35 & \\
\hline \multicolumn{9}{|c|}{ Do you believe that reading book can cause damage to the eye? } & \multirow{2}{*}{ - } \\
\hline Yes/no & $23 / 30$ & $18 / 21$ & $15 / 23$ & $2 / 4$ & $16 / 29$ & $33 / 38$ & $15 / 47$ & $8 / 11$ & \\
\hline \multicolumn{9}{|c|}{ Do you think devices like mobile phones and tablets cause eye disease? } & \multirow[b]{2}{*}{-} \\
\hline Yes/no & $51 / 4$ & $33 / 6$ & $35 / 2$ & $6 / 0$ & $43 / 3$ & $66 / 5$ & $61 / 1$ & $18 / 2$ & \\
\hline \multicolumn{9}{|l|}{ Confidence index } & \\
\hline To the pharmacy & $2.5 \pm 0.8$ & $2.5 \pm 0.8$ & $2.2 \pm 0.8$ & $2.1 \pm 0.7$ & $2.3 \pm 0.9$ & $2.2 \pm 0.8$ & $2.3 \pm 0.8$ & $2.5 \pm 1$ & \\
\hline To the family doctor & $3.2 \pm 1.0$ & $3.4 \pm 0.8$ & $3.2 \pm 1$ & $3.3 \pm 0.8$ & $2.7 \pm 0.8$ & $3.0 \pm 1$ & $3.0 \pm 0.8$ & $2.8 \pm 1$ & \\
\hline To the nurse & $2.2 \pm 0.8$ & $2.2 \pm 0.8$ & $2.1 \pm 0.5$ & $1.8 \pm 0.5$ & $3.0 \pm 0.9$ & $2.8 \pm 1$ & $2.3 \pm 0.9$ & $2.3 \pm 0.7$ & \\
\hline To the ophthalmologist & $4.8 \pm 0.6$ & $4.9 \pm 0.5$ & $4.9 \pm 0.5$ & $5 \pm 0$ & $4.8 \pm 0.6$ & $4.7 \pm 0.7$ & $4.8 \pm 0.5$ & $4.8 \pm 0.2$ & \\
\hline To the optician & $2.3 \pm 0.9$ & $2.1 \pm 0.9$ & $2.7 \pm 1$ & $2.8 \pm 0.8$ & $2.2 \pm 1$ & $2.3 \pm 0.9$ & $2.5 \pm 1$ & $2.6 \pm 1.1$ & \\
\hline $\begin{array}{l}\text { TCGTHB approved drugs are } \\
\text { more effective } T / F\end{array}$ & $10 / 31$ & $1 / 38$ & $5 / 30$ & $0 / 5$ & $12 / 31$ & $15 / 51$ & $14 / 44$ & $3 / 12$ & 0.084 \\
\hline $\begin{array}{l}\text { TCGTHB approved drugs are } \\
\text { safer T/F }\end{array}$ & $10 / 32$ & $2 / 37$ & $7 / 28$ & $0 / 5$ & $9 / 35$ & $25 / 42$ & $22 / 36$ & $3 / 12$ & 0.003 \\
\hline $\begin{array}{l}\text { TCGTHB approved drugs have } \\
\text { fewer side effects T/F }\end{array}$ & $17 / 24$ & $2 / 37$ & $19 / 16$ & $2 / 3$ & $20 / 23$ & $29 / 38$ & $28 / 30$ & $6 / 9$ & 0.001 \\
\hline $\begin{array}{l}\text { TCGTHB approved drugs are } \\
\text { more favorable T/F }\end{array}$ & $11 / 30$ & $2 / 37$ & $14 / 21$ & $0 / 5$ & $15 / 30$ & $22 / 45$ & $25 / 32$ & $5 / 10$ & 0.004 \\
\hline $\begin{array}{l}\text { TCGTHB approved drugs are } \\
\text { cheaper } \mathrm{T} / \mathrm{F}\end{array}$ & $32 / 11$ & $21 / 15$ & $29 / 6$ & $3 / 2$ & $36 / 9$ & $45 / 20$ & $37 / 20$ & $10 / 6$ & 0.248 \\
\hline $\begin{array}{l}\text { Imported drugs are more } \\
\text { effective } T / F\end{array}$ & $29 / 17$ & $15 / 22$ & $27 / 7$ & $3 / 2$ & $26 / 18$ & $24 / 43$ & $22 / 38$ & $8 / 8$ & $<0.001$ \\
\hline Imported drugs are safer $\mathrm{T} / \mathrm{F}$ & $19 / 26$ & $14 / 23$ & $20 / 14$ & $2 / 3$ & $19 / 25$ & $15 / 53$ & $11 / 49$ & $7 / 9$ & 0.001 \\
\hline $\begin{array}{l}\text { Imported drugs have fewer } \\
\text { side effects } T / F\end{array}$ & $6 / 39$ & $9 / 29$ & $11 / 23$ & $2 / 3$ & $14 / 30$ & $12 / 54$ & $10 / 50$ & $4 / 12$ & 0.240 \\
\hline $\begin{array}{l}\text { Imported drugs are more } \\
\text { favorable drugs } \mathrm{T} / \mathrm{F}\end{array}$ & $20 / 26$ & $10 / 27$ & $11 / 22$ & $1 / 4$ & $17 / 25$ & $21 / 45$ & $16 / 44$ & $6 / 9$ & 0.575 \\
\hline $\begin{array}{l}\text { Imported drugs are cheaper } \\
T / F\end{array}$ & $18 / 26$ & $8 / 29$ & $13 / 21$ & $2 / 3$ & $19 / 25$ & $26 / 40$ & $15 / 45$ & $6 / 10$ & 0.304 \\
\hline
\end{tabular}

TCGTHB: The Republic of Turkey, Ministry of Food Agriculture and Livestock, MED: Medicine, DEN: Dentistry, MID: Midwifery, NUR: Nursing, T: True, F: False 
NUR4 differ from MID2; MED6 differ from MID2; DEN2, NUR4 differ from MID2; finally NUR2, NUR4 differ from MID2 group ( $p=0.001$ ). $77.9 \%$ of these students disagreed with the idea that drugs from abroad have less side effects $(p=0.240)$ and $66.4 \%$ stated that it was not suitable for most patients $(p=0.575)$. Only $35 \%$ of all students (306 students) thought that drugs from abroad would reduce the cost of treatment due to rapid and definitive treatment $(p=0.304)$.

When the students were asked whether they would recommend medication to their relatives in case of any eye disease; in all groups, positive responses were $8.3 \%(p=0.084)$. The distribution of positive responses according to groups was as follows: MED2 $13.7 \%$, MED6 23.7\%, DEN2 2.9\%, NUR2 8.9\%, NUR4 7\%, MID2 $1.6 \%$. Although $91.7 \%$ of all students answered no to the above mentioned question; then the question "Which group of drugs do you recommend for eye diseases?" they recommended medications like pain killers, antibiotics, vitamins, and anti-allergic drugs and marked one or more of these drugs (Table 4). The most recommended drugs were an anti-allergic and antibiotic group of drugs.

\section{Discussion}

Precautions concerning eye health and wise approaches are important to prevent lifetime damages to the eye. However, sometimes insufficient information, false beliefs, and practices can be harmful. When the midwife, nurse, or family physician fails to provide guidance or refer the patient in situations like premature retinopathy, one of the most important eye emergencies, the patient can develop retinal detachment, angle-closure glaucoma, and painful absolute blindness in both eyes. Dentists, nurses, and midwives need to have as much information as family physicians about diseases that can cause blindness such as retinopathy of prematurity, diabetic retinopathy, and glaucoma to make the patient reach ophthalmologists for early diagnosis and treatment. Because all healthcare professionals can be placed in many different units, as it is happening during the pandemic of coronavirus disease-2019, they are expected to have sufficient knowledge not only in basic concepts like rational use of drugs but also in subjects that require expertise mainly emergencies and diseases that may cause acute blindness.

$51.6 \%$ of the students had refractive errors, the most frequent was myopia with $27.6 \%$. As expected, most of the students use glasses to correct the refractive error. In similar two studies, $56.9 \%$ of medical faculty students had refractive errors, of which myopia $(63.3 \%)$ was the most frequent $(7,8)$. In another study conducted in our country among medical faculty students, $32.9 \%$ were found to have myopia (9). This situation is a very big concern because as in our study, even the fact that it was performed only in a certain community, refractive error emerging in half of the community in these studies. According to a study published in 2016, half of the world population will be myopic in 2050 (10). However the previously mentioned studies show that this prediction is almost a reality before 2020 .

Netto et al. (11) reported that medical faculty students were evaluated with the Ishihara color vision tests, the rate of dyschromatopsia was found

\begin{tabular}{|c|c|c|c|c|c|c|c|c|}
\hline Educational background & MED2 & MED6 & DEN2 & DEN5 & NUR2 & NUR4 & MID2 & MID4 \\
\hline \multicolumn{9}{|c|}{ Would you recommend any medication? } \\
\hline Yes/no & $7 / 44$ & $9 / 29$ & $1 / 33$ & $0 / 5$ & $4 / 41$ & $5 / 66$ & $1 / 61$ & $0 / 19$ \\
\hline Pain killer & 4 & 11 & 9 & - & 11 & 11 & 6 & 1 \\
\hline Antibiotic & 6 & 14 & 4 & - & 11 & 16 & 9 & 4 \\
\hline Drugs for the common cold & 2 & 4 & 1 & - & - & 5 & - & - \\
\hline Vitamins & 2 & 2 & 6 & - & 7 & 8 & 4 & - \\
\hline Drugs for allergy & 11 & 15 & 12 & - & 19 & 14 & 20 & 4 \\
\hline Eye drop & 0 & 0 & 1 & - & 2 & 0 & 1 & 0 \\
\hline
\end{tabular}


to be $2.6 \%$ and $81.2 \%$ of these participants reported to have already been aware of this disease. In our study, $48.2 \%$ of the students, although have not been submitted to color vision tests stated that they did not have any defects. However, concerning this statement, even though they did not go to the ophthalmologist, they may have got aware of their situation after being submitted to tests by their family physicians to get a health report for school or driving license admission. For this reason, we think the rate of dyschromatopsia in our study is similar to the study of Netto et al. (11).

We asked simple questions to the students about daily life because we did not mean to transform the questionnaire into an exam but to assess for the level of knowledge and awareness. Despite this, the students' response rate was low. The students do not know the importance of sunglasses for eye health. We expected all of our students to know that ocular involvement may occur in the course of chronic diseases, and $60 \%$ of the $6^{\text {th }}$-year medical student's group were able to write two correct diseases. When asked about what kind of eye disease that develops in a premature newborn, $1 / 3$ of all students wrote anything including jaundice and stye; only half of them could establish a relationship between preterm birth and diseases such as retinopathy, strabismus, and refractive errors. It is important to point out that medicine, dental, nursing, and midwifery students graduating in a month, do not remember or think about a serious disease such as retinopathy, which can be partially managed with early interventions. Some students were not able to write conjunctivitis as one of contagious eye diseases and did not recommend anything to protect the eye from diseases. They think that a routine eye examination should be performed every 6 months. In a study conducted with 196 family physicians in Ankara, $87.2 \%$ of the residents thought that the ophthalmology education provided in the medical faculty was insufficient (12), this percentage is very high and supports the results of our study. It is worrisome that healthcare professionals that will take part in primary care will not be able to respond to basic needs.

Considering the individual errors on the rational use of drugs, physicians, patients, nurses, and pharmacists have a very important role and responsibility $(1,13)$. However, in our society, students who start higher education apart from being valued, are considered as a source of information in the field of health to the people around them. This situation may be due to the difficulty of the patients in accessing health services and or could be also related to the trust in their relatives or people they know. The level of knowledge of all these students is important not only in counseling but also because they can personally be sick. The Ministry of Health declared that $44.5 \%$ of the students did not receive the training of "rational drug use", which is a compulsory course of vocational training. This high rate suggests the need of reviewing the courses in the curriculum and increasing the number of courses related to the rational use of drugs. Students did not know TÜFAM and that it is the entity where we report adverse effects. Students mostly left the information questions about diseases of the eye, blank. For eye health and medications, they chose the "I mostly check from the internet" option as the source of information, and books remained among not preferred sources. In the questions about drugs, except for medical students, all the others claimed to have knowledge above-average regardless of the education year differences. Despite the advance in years of education, medical students feel less competent than midwifery and nursing students in terms of their level of knowledge, the reason may be because they have had the opportunity to test and evaluate themselves in different situations, as well as the opportunity approach patients in the clinical and outpatient clinics environment and therefore may have increased their awareness concerning this topic. We think that measuring the knowledge and awareness of nursing and midwifery students with an examination system at the end of the course, as in the specialty examination for medicine (TUS) would be good.

Our students could not give satisfactory answers to the question of eye disease that can be prevented with sunglasses. We would expect them to know that sunglasses can protect from excessive ultraviole in our geography causing cataract or pterygium, or to know that because of high cosmetic concerns nowadays, it can prevent wrinkles that may develop around the eyes, so the rate of using sunglasses would be higher (14-16). Glasses are also important among personal protective equipment (PPE) in dangerous or risky jobs. Although dentistry students attach the most to the 
importance of its use, we found that these students graduated before they fully gained the habit of using PPE.

As advances in the year of education, there is an increase in the rate of beliefs that reading books is disruptive to the eye. On the other hand, $39 \%$ of all students believe that reading books, $93.2 \%$ of them believe that gadgets such as mobile phones and tablets damage the eye. Reading books and using digital displays such as mobile phones or tablets are both considered activities of near vision. Many publications suggest that these near vision activities also increase the frequency and degree of myopia (17-19). Concerning this, we can conclude that it is possible to conclude that our students' awareness is high.

The study found that students' trust in ophthalmologists was high, while last year nursing students trusted nurses more than family physicians.

We also questioned their attitude towards products approved by TCGTHB in this study. The number of students who say that these products are more effective and safer than the drugs approved by the Ministry of Health decreases rapidly as the years of education increase in medical and dentistry students. We also noticed that $20 \%$ and $37.3 \%$ of nursing and midwifery students graduate with beliefs that agricultural products are more effective and safer to use than drugs in treatment. While $5.1 \%$ of $6^{\text {th }}$-year medical students agree that these products have fewer side effects than drugs, as well as $40-43.3 \%$ of students from other faculties. Again, only $5.1 \%$ of $6^{\text {th }}$ year medical students agreed to administer these to patients, while $32.8-33.3 \%$ of other faculty students found it suitable.

Interestingly, when we look at all the students, 70.5\% believe that TCGTHB approved products offer a cheaper treatment option. Although they say these products are ineffective and may have side effects, contradicting themselves, seeing them as a cheap treatment option. Some of the products sold in the market are more expensive than the drugs, but the most important is the cost of the treatment, not the price of the daily used drugs. The price of the drug in this case is like the tip of the iceberg. Many factors such as duration of treatment, possible side effects, and supportive treatments added to the cost of treatment. A non-therapeutic product may cause more waste of time and the existing disease to become more problematic, which will increase the cost. With similar questions, we wanted to evaluate the students' belief in imported drugs. With the increase in years of education, the belief of students that these drugs are more effective and safer decreased, still at the level of $35-40 \%$. The belief that it has few side effects is $22.1 \%$, and the belief that it is suitable for most patients is $33.6 \%$. 35 percent of students think that the cost of fast and definite treatment was cheap.

In the study, even the second-year students of all faculties stated that they recommended drugs to their relatives. In our country, where the Ministry of Health gives importance to studies related to the rational use of drugs, considering that the authority to prescribe drugs for patients is only of medical doctors and dentists, administering or recommending medication by students may cause problems. Also important to notice that the use of antibiotics is also easily recommended. In our society, using drugs without consulting a physician is very common (1). Prevention of medical errors is important in terms of damages both to the patient and to the economic system; education concerning this issue should be reinforced during university education.

\section{Conclusion}

Considering the level of knowledge and education background on eye diseases and rational use of drugs among the students at the beginning and those at the end of the course and about to receive their diplomas in one month, most students were not able to answer even the simplest questions, and among those who answered there was a high and remarkable rate of mistakes were. To increase their level of knowledge about these topics, asking a doctor, and checking on the internet was a priority over books. Concerning their understanding of the importance of preventive treatment observing their attitudes and behaviors, we noticed that during the education years they have not sufficiently acquired good habits on the topic. Besides this, concerning the knowledge of drugs, regardless of the year of education, nursing and midwifery students scored themselves above-average. Parallelly, in that level of education, scoring themselves a high level of knowledge, most students recommend allergy and antibiotic drug groups to patients which is out of their competence and illegal. We think that especially for 
nursing and midwifery students taking an exam like medical and dentistry students will be beneficial in terms of increasing their quality of education and training as well as benefits for the health-care of the society.

Ethics

Ethics Committee Approval: The NonInterventional Clinical Research Ethics Committee of Aydın Adnan Menderes University approved the survey (protocol no: 2019/74, date: 25.04.2019).

Informed Consent: Since students voluntarily participated in the survey, no signed consent form was needed.

Peer-review: Externally peer-reviewed.

Authorship Contributions

Concept: A.I.A.Ü., B.D., Design: A.I.A.Ü., F.J.L.J., B.D., Supervision: A.I.A.Ü., B.D., Data Collection or Processing: A.I.A.Ü., F.J.L.J., B.D., Analysis or Interpretation: A.I.A.Ü., F.C., I.K.Ö., A.Ü., B.D., Literature Search: A.I.A.Ü., F.J.L.J., A.Ü., B.D., Critical Review: A.I.A.Ü., F.J.L.J., I.K.Ö., A.Ü., B.D., Writing: A.I.A.Ü., A.Ü., B.D.

Conflict of Interest: No conflict of interest was declared by the authors.

Financial Disclosure: The authors declared that this study received no financial support.

\section{References}

1. Demirci B, Ayhan FC, Abacıgil F. Eczanelerde Çalışan Personelin Akılıı İlaç Uygulamalarındaki Tutumu: Kesitsel Çalışma. Med Bull Haseki 2019; 57: 339-44.

2. Flaxman SR, Bourne RRA, Resnikoff $S$, Ackland P, Braithwaite T, Cicinelli MV, et al. Global causes of blindness and distance vision impairment 1990-2020: a systematic review and meta-analysis. Lancet Glob Health 2017; 5: 1221-34.

3. Abdianwall MH, Dogan BG. Eye health knowledge of early childhood and classroom education departments' students: A descriptive study from Turkey. Turk J Public Health 2019; 17: 169-82.

4. Solebo AL, Teoh L, Rahi J. Epidemiology of blindness in children. Arch Dis Child 2017; 102: 853-7.
5. Cetin E, Yaman A, Berk AT. Etiology of childhood blindness in Izmir, Turkey. European Journal of Ophthalmology 2004; 14: 531-7.

6. İskit AB. Akılcı ilaç kullanımı. STED 2006; 15: 4-5.

7. Dey AK, Chaudhuri SK, Jana S, Ganguly P, Ghorai S, Sarkar A. Prevalence of refractive errors in medical students. Int J Health Sci Res 2014; 4: 98-102.

8. Ebeigbe JA, Kio F, Okafor LI. Attitude and beliefs of Nigerian undergraduates to spectacle wear. Ghana Med J 2013; 47: 70-3.

9. Onal S, Toker E, Akingol Z, Arslan G, Ertan S, Turan C, et al. Refractive errors of medical students in Turkey: one year followup of refraction and biometry. Optom Vis Sci 2007; 84: 175-80.

10. Holden BA, Fricke TR, Wilson DA, Jong M, Naidoo KS, Sankaridurg $P$, et al. Global Prevalence of Myopia and High Myopia and Temporal Trends from 2000 through 2050. Ophthalmology 2016; 123: 1036-42.

11. Netto AA, Neumaier R, Rodrigues IK, Astolfi M. Prevalência de discromatopsia entre estudantes de medicina da Universidade Federal de Santa Catarina. Arquivos Catarinenses de Medicina 2006; 35: 41-6.

12. Biten H, Koç EM, Özçelik DÇ, Kahveci R, Kasım I, Şencan I, et al. Birinci basamakta göz hastalarına yaklaşım ile ilgili aile hekimliği asistanlarının yeterliliklerinin değerlendirilmesi. Journal of Clinical And Experimental Investigation 2015; 6: 369-74.

13. Uzun Ş, Arslan F. İlaç uygulama hataları. Türkiye Klinikleri J Med Sci 2008; 28: 217-22.

14. Kamari F, Hallaj S, Dorosti F, Alinezhad F, Taleschian-Tabrizi N, Farhadi F. et al. Phototoxicity of environmental radiations in human lens: revisiting the pathogenesis of UV-induced cataract. Graefe's Archive for Clinical and Experimental Ophthalmology 2019; 257: 2065-77.

15. Gümüş E, Yaşar İ. Pterjium oluşmasında mesleğin etkileri. Turk J Ophthalmol 2013; 43: 245-9.

16. Uslu M, Karaman G, Savk E, Sendur N. Adnan Menderes Üniversitesi hekimlerinin deri kanserleri ve güneşin etkileri konusundaki bilgi düzeyleri ile güneşten korunma davranışlarının değerlendirilmesi. ADÜ Tıp Fakültesi Dergisi 2006; 7: 5-10.

17. Dirani M, Crowston JG, Wong TY. From reading books to increased smart device screen time. Br J Ophthalmol 2019; 103: 1-2.

18. Lanca C, Saw SM. The association between digital screen time and myopia: A systematic review. Ophthalmic Physiol Opt 2020; 40: 216-29.

19. Rocha JC, Gondim EL, Braga FT, Dantas FJ, Temporini ER, KaraJosé N. Ocular health myths among a hospital staff. Ophthalmic Epidemiol 1997; 4: 107-13. 